\title{
Bio-efficacy of some insecticides against cotton mealybug, Phenacoccus solenopsis Tinsley (Hemiptera: Pseudococcidae)
}

\author{
Atanu Seni*, Bhima Sen Naik \\ Orissa University of Agriculture and Technology, AICRIP, RRTTS, Chiplima-768025, Sambalpur, Odisha \\ *E-mail: atanupau@gmail.com
}

\begin{abstract}
Laboratory bioassay of eight insecticides namely Chlorpyriphos 20 EC, Ethiprole+ imidacloprid 80 WG, Pymetrozine 50 WP, Lamda cyhalothrin 4.9 CS, Imidacloprid 30.5 SC, Acephate 95 SG, Thiacloprid 240 SC and Fipronil 5 SC was done against cotton mealybug, Phenacoccus solenopsis Tinsley. Among insecticides, Lamda cyhalothrin 4.9 CS was the most toxic with the lowest $L D_{50} 16.03$ ppm followed by Chlorpyriphos 20 EC $\left(L D_{50} 27.56\right.$ ppm), Ethiprole+ imidacloprid $80 \mathrm{WG}\left(L D_{50}\right.$ $44.82 \mathrm{ppm})$, Imidacloprid $30.5 \mathrm{SC}$ ( $\left.L D_{50} 80.68 \mathrm{ppm}\right)$, Thiacloprid 240 SC ( $L D_{50} 87.13$ ppm), Pymetrozine $50 \mathrm{WP}$ (LD 181.45 ppm), Acephate $95 S G$ (LD $35359.61 \mathrm{ppm})$, Fipronil 5 SC ( $L D_{50} 705.59$ ppm).
\end{abstract}

Keywords - Bioassay, Lamda cyhalothrin 4.9 CS, insecticides, cotton mealybug, $L D_{50}$,

\section{INTRODUCTION}

Phenacoccus solenopsis was initially described by Tinsley [12] from specimens infesting the roots and stems of Boerhavia spicata and Kallstroemia californica within the nests of ants, Solenopsis geminata, in New Mexico, USA. It is a bisexual species and completed many generation in a year. Adult females are about 2 to $5 \mathrm{~mm}$ long and 2 to $4 \mathrm{~mm}$ wide. They are covered with a powdery, waxy secretion with six pairs of transverse, dark bands that are located across the pro- to meta-thoracic segments. A series of waxy filaments extend from around the margin of the body with the pair of terminal filaments longest. The ovisac is composed of fluffy, loose-textured wax strands [4]. They are polyphagous in nature and infest more than 154 plant species of 53 families comprising 20 field and horticultural crops, 45 ornamentals, 64 weeds and 25 bushes and trees [1, 2]. The insect weakens the plants by sucking the sap from leaves, twigs, stems, and sometimes from the roots and also from fruiting bodies. Later, the entire plants become stunted and shoot tips develop a bushy appearance and ultimately causing havoc loss of the farmers. Due to their short life cycle they are capable to increase their numbers and spread rapidly within very short span of time in favourable environmental condition. For this, other control measures except chemical control is time consuming. So, chemical control is the last resort to check the mealybug population within short period of time. Keeping in view, the present study aims to evaluate the efficacy of certain new and conventional insecticides against this pest in order to monitoring insecticide resistance and to identify the potential molecules for developing proper management strategy against this pest.

\section{MATERIALS AND METHODS}

The present experiment was conducted in the Regional Research and Technology Transfer Station (OUAT), Chiplima, Sambalpur, Odisha during February-March, 2016.

Source of the insecticides

Commercial formulations of Chlorpyriphos 20 EC (Sumitomo Chemical India Pvt. Ltd.), Ethiprole+ imidacloprid 80 WG (Bayer Crop Science Ltd), Pymetrozine 50 WP (Syngenta Korea Ltd.), Lamda cyhalothrin 4.9 CS (Safex Chemicals [India] Ltd.), Imidacloprid 30.5 SC (Coromandel Agrico Pvt. Ltd.), Acephate 95 SG (Rallis India Ltd.), Thiacloprid 240 SC (Bayer India Ltd.) and Fipronil 5 SC (Makhteshim- Agan India Pvt. Ltd.) were obtained from respective principal manufactures. The proprietary products were used to prepare stock solution in distilled water from which further concentrations were prepared subsequently by serial dilution (six to eight different concentrations were used for bioassay). Each treatment including untreated control was replicated thrice.

Bioassay test

Leaf dip method 
Laboratory bioassay was done by leaf dip method [6, 9], unsprayed chrysanthemum leaves were taken and after washed in fresh water those leaf discs were dipped in the test solutions for 5 minutes with gentle agitation. Then they were placed on tissue papers for drying. On drying, these were placed in petri dish and petioles of the leaves were wrapped by water-soaked cotton. On each leaf disc, 20 mealybugs (3rd instar) taken from unsprayed chrysanthemum plants were placed with a fine camel hair brush and the test containers were covered with lid.

\section{Data analysis}

The responses (mortality) of mealybugs were recorded after 24 hours post-exposure period. The mortality data were subjected to log-dose probit analysis to generate estimates of a lethal concentration. Probit analysis and lethal concentrations were calculated according to Finney's method by using Polo plus software. This type of bioassay provides an exposure that is more similar that the insects would experience under field conditions.

\section{RESULTS AND DISCUSSION}

The $\mathrm{LD}_{50}$ values obtained from probit analysis for mortality values after 24 hours of each insecticide applied are given in the table 1. According to the results of probit analysis of different tested insecticides, it is found that Lamda cyhalothrin $4.9 \mathrm{CS}$ was the most toxic with the lowest $\mathrm{LD}_{50}$ $16.03 \mathrm{ppm}$ to mealybug, $P$. solenopsis followed by Chlorpyriphos 20 EC ( $\mathrm{LD}_{50} 27.56$ ppm), Ethiprole+ imidacloprid $80 \mathrm{WG}$ (LD $\mathrm{LD}_{50} 44.82 \mathrm{ppm}$ ), Imidacloprid 30.5 $\mathrm{SC}\left(\mathrm{LD}_{50} 80.68 \mathrm{ppm}\right)$, Thiacloprid $240 \mathrm{SC}\left(\mathrm{LD}_{50} 87.13\right.$ $\mathrm{ppm})$, Pymetrozine $50 \mathrm{WP}\left(\mathrm{LD}_{50} 181.45 \mathrm{ppm}\right)$, Acephate 95 $\mathrm{SG}\left(\mathrm{LD}_{50} 359.61 \mathrm{ppm}\right)$, Fipronil $5 \mathrm{SC}\left(\mathrm{LD}_{50} 705.59 \mathrm{ppm}\right)$. As Fipronil $5 \mathrm{SC}$ has the highest $\mathrm{LD}_{50}$ value that refers it is the least effective among all tested insecticides against $P$. solenopsis. Qiao-li et al., [8] studied the relative toxicity of some insecticides against 3rd instar nymphs of cotton mealybug with leaf dipping method and found that after 24 hours of treatment, relative toxicity of some insecticides from high to low was lambda-cyhalothrin, profenofos, chlorpyrifos, avermectins, phoxim, carbosulfan, spinosad, chlorfenapyr, beta cypermethrin, methomyl, emamectin benzoate, triazophos, petroleum oil, and rotenone respectively. Seni and Sahoo, [10] studied the bio-efficacy of some insecticides against papaya mealybug, Paracoccus marginatus and observed that after 24 hours, Chlorpyriphos $20 \mathrm{EC}\left(\mathrm{LC}_{50} 21 \mu \mathrm{l} / \mathrm{l}\right)$ and Thiamethoxam $25 \mathrm{WG}\left(\mathrm{LD}_{50} 44\right.$ $\mathrm{mg} / \mathrm{l})$ were the most toxic and Buprofezin $25 \mathrm{SC}\left(\mathrm{LC}_{50}\right.$ $1000 \mu \mathrm{l} / \mathrm{l})$ was the least toxic among the insecticides tested in bioassay test (Potato dip method) and in case of field trials, Thiamethoxam 25 WG, Spirotetramat 240 EC, Imidacloprid 17.8 SL, Dimethoate 30 EC, Lamdacyhalothrin $5 \mathrm{EC}$ and Buprofezin $25 \mathrm{SC}$ were found effective for management of the papaya mealybug. Tanwar et al., [11] reported that chlorpyriphos was effective against mealybug both in laboratory bioassay and in the field. Nagrare et al., [7] tested some insecticides against $P$. solenopsis under the laboratory conditions and observed the better efficacy of chlorpyriphos followed by triazophos, diclorvos, endosulfan and spinosad. Banu et al., [3] also found effectiveness of chlorpyriphos against $P$. solenopsis and Paracoccus marginatus in laboratory condition. Mandal et al., [5] conducted laboratory bioassay to determine the relative toxicity of some insecticides against 3rd instar nymphs of cotton mealybug, $P$. solenopsis and found that after 24 hours of exposure, chlorpyriphos $20 \mathrm{EC}$ was most effective followed by followed by dichlorvos $75 \mathrm{EC}$, triazophos 40 EC and spinosad 45 SC. Seni and Naik, [9] studied the Laboratory bioassay of eight insecticides at Chiplima, Odisha against mustard aphid, Lipaphis erysimi (Kalt.) using leaf dip method in 2016 and found that among insecticides, chlorpyriphos $20 \mathrm{EC}$ was the most toxic $\left(\mathrm{LD}_{50}\right.$ $5.38 \mathrm{ppm})$ followed by imidacloprid $30.5 \mathrm{SC}\left(\mathrm{LD}_{50} 22.14\right.$ $\mathrm{ppm})$, ethiprole+ imidacloprid $80 \mathrm{WG}\left(\mathrm{LD}_{50} 22.94 \mathrm{ppm}\right)$, thiacloprid $240 \mathrm{SC}\left(\mathrm{LD}_{50} 27.17 \mathrm{ppm}\right.$ ), pymetrozine 50 WP (LD $\mathrm{LD}_{50} 25.59 \mathrm{ppm}$ ), lamda cyhalothrin 4.9 CS (LD ${ }_{50} 31.34$ ppm), acephate $95 \mathrm{SG}$ ( $\left.\mathrm{LD}_{50} 111.22 \mathrm{ppm}\right)$, fipronil $5 \mathrm{SC}$ $\left(\mathrm{LD}_{50} 234.15 \mathrm{ppm}\right)$. The value obtain from this experiment can be used in future for monitoring surveys or for the immediate purpose of comparing the current results to that of a previously determined $\mathrm{LD}_{50}$ to determine the susceptibility of the target insects has shifted or not. The $\mathrm{LD}_{50} \mathrm{~S}$ can also be used to examine seasonal changes in insecticide susceptibility or compare responses among species or insecticide [6].

\section{CONCLUSION}

Thus, the present study revealed that among all the tested chemicals Lamda cyhalothrin 4.9 CS, Chlorpyriphos 20 EC, Ethiprole+ imidacloprid $80 \mathrm{WG}$, Imidacloprid $30.5 \mathrm{SC}$, Thiacloprid 240 SC may be recommended for effective management of cotton mealybug, P. solenopsis and the value of $\mathrm{LD}_{50}$ of different insecticide against cotton mealybug be used in future for monitoring of any resistance development in cotton mealybug.

\section{ACKNOWLEDGEMENT}

The authors are highly thankful to Orissa University of Agriculture and Technology, Bhubaneswar for financial assistance. 
Table.1: Dosage mortality response and LD $D_{50}$ values of different insecticides for Phenacoccus solenopsis after 24 hours of

exposure

\begin{tabular}{|l|l|l|l|l|l|}
\hline Insecticide & $\begin{array}{l}\text { Heterogeneit } \\
\mathbf{y}\end{array}$ & Slope & $\begin{array}{l}\text { LD50 } \\
(\mathbf{p p m})\end{array}$ & Fiducial limits & $\begin{array}{l}\text { Relative } \\
\text { toxicity }\end{array}$ \\
\hline Chlorpyriphos 20 EC & 0.68 & $3.621 \pm 0.579$ & 27.56 & $22.025-34.793$ & 25.60 \\
\hline $\begin{array}{l}\text { Ethiprole+ imidacloprid } \\
80 \mathrm{WG}\end{array}$ & 1.03 & $3.466 \pm 0.548$ & 44.82 & $31.742-64.481$ & 15.74 \\
\hline Pymetrozine 50 WP & 0.78 & $3.131 \pm 0.494$ & 181.45 & $142.584-234.989$ & 3.89 \\
\hline $\begin{array}{l}\text { Lamda cyhalothrin 4.9 } \\
\text { CS }\end{array}$ & 0.64 & $3.076 \pm 0.564$ & 16.03 & $11.969-20.566$ & 44.02 \\
\hline Imidacloprid 30.5 SC & 0.15 & $3.887 \pm 0.634$ & 80.68 & $64.731-100.367$ & 8.74 \\
\hline Acephate 95 SG & 1.46 & $2.917 \pm 0.472$ & 359.61 & $227.687-645.910$ & 1.96 \\
\hline Thiacloprid 240 SC & 0.85 & $3.582 \pm 0.606$ & 87.13 & $68.415-109.113$ & 8.10 \\
\hline Fipronil 5 SC & 0.16 & $4.491 \pm 0.791$ & 705.59 & $572.615-866.168$ & 1 \\
\hline
\end{tabular}

\section{REFERENCES}

[1] Alam, S. F., Seni, A. and Sahoo, A. K. 2011. Biology of the mealybug, Phenacoccus solenopsis Tinsley (Pseudococcidae: Hemiptera) on sprouted potato and brinjal plant. The Journal of Plant Protection Sciences, 3(2): 32-36.

[2] Arif, M. I., Rafiq, M., Ghaffar, A. 2009. Host plants of cotton mealybug (Phenacoccus solenopsis): a new menace to cotton agro-ecosystem of Punjab. International Journal of Agricultural Biology, 11: 163-167.

[3] Banu, J. G., Surulivelu, T. Amutha, M. Gopalakrishnan, N. 2010. Laboratory evaluation of insecticide and biopesticides against Phenacoccus solenopsis and Paracoccus marginatus infesting cotton. Journal of Biopesticides, 3(1): 343-46.

[4] Kosztarab, M. 1996. Scale insects of northeastern North America: identification, biology, and distribution. Martinsville, USA: Virginia Museum of Natural History, vii + 650 pp.; 34 pp. of ref.

[5] Mandal, D., Bhowmik, P., Halder, P., Chatterjee, M. L. 2013. Determination of relative toxicity and base line data of different insecticides against cotton mealybug (Phenacoccus solenopsis Tinsley). The Journal of Plant Protection Sciences, 5(1): 26-31.

[6] Miller, A. L., Tindall, K., Leonard, B. R. 2010. Bioassays for monitoring insecticide resistance. Journal of Visualized Experiments; 46: e2129, doi:10.3791/2129.

[7] Nagrare, V. S., Kranthi, S., Dhara, R. K., Jothji, B., Amutha, M., Deshmukh, A. J., Bisane, K. D., Kranthi, K. R. 2011. Compendium of cotton mealybugs. Institute for Cotton Research, Nagpur, India. P. 42.

[8] Qiao-li, L., Guang-wen, L., Yong-yue, L. 2014. Toxicity of 14 insecticides to cotton mealybug Phenacoccus solenopsis Tinsely with leaf dipping method. Guangdong Agricultural Sciences. 201406.

http://en.cnki.com.cn/Article_en/CJFDTOTALGDNY201406027.htm dated 06. 12.2017.

[9] Seni, A, Naik, B. S. 2017. Bio-efficacy of some insecticides against mustard aphid, Lipaphis erysimi (Kalt.) (Hemiptera: Aphididae). Journal of Entomology and Zoology Studies, 5(6): 541-543.

[10] Seni, A., Sahoo, A. K. 2015. Efficacy of certain insecticides on papaya mealybug, Paracoccus marginatus Williams \& Granara de Willink (Hemiptera: Pseudococcidae). Journal of Entomology and Zoology Studies, 3(4): 14-17.

[11] Tanwar, R. K., Jeyakumar, P., Monga, D. 2007. Mealybugs and their management. Technical Bulletin No. 19, 2007, NCIPM, New Delhi, India. p. 12.

[12] Tinsley, J. D. 1898. An ants'-nest coccid from New Mexico. The Canadian Entomologist, $30: 47-48$. 